Case Report

\title{
A 75-Year-Old Female with Hemoptysis and Recurrent Respiratory Infections
}

\author{
Mary S. Baker ${ }^{1}$ and Khalil Diab ${ }^{2}$ \\ ${ }^{1}$ Pulmonary \& Critical Care Medicine, Division of Pulmonary, Allergy, Critical Care Medicine, and Sleep Medicine, \\ Indiana University School of Medicine, Gatch Clinical Building, Room 260, 541 N. Clinical Dr., Indianapolis, IN 46202-5111, USA \\ ${ }^{2}$ Clinical Medicine, Division of Pulmonary, Allergy, Critical Care Medicine, and Sleep Medicine, Indiana University School of Medicine, \\ 550 N. University Boulevard, UH 4903, Indianapolis, IN 46202, USA
}

Correspondence should be addressed to Khalil Diab; kdiab@iu.edu

Received 7 March 2013; Accepted 4 April 2013

Academic Editors: C. Diez, M. Egi, and J. Starkopf

Copyright ( 2013 M. S. Baker and K. Diab. This is an open access article distributed under the Creative Commons Attribution License, which permits unrestricted use, distribution, and reproduction in any medium, provided the original work is properly cited.

\begin{abstract}
This paper describes the case of a 75-year-old female who presented with significant hemoptysis over a 7-10 day period. She had a history of a left lower lobectomy 10 years prior for a "lung abscess." She subsequently had multiple episodes of cough, fevers, and possible pneumonia treated with multiple courses of Amoxicillin and Amoxicillin/Clavulanate. Review of her chest CT upon presentation to the hospital showed a large necrotic lingular infiltrate, which had been progressively increasing in size over at least one year. Bronchoscopy showed a yellowish, soft round body in the superior lingular subsegment. Endobronchial and transbronchial biopsies showed actinomyces species. This is a very interesting case of indolent actinomycosis which we suspect had a very slow progressive course secondary to the multiple courses of antibiotics that the patient was treated with.
\end{abstract}

\section{Case Report}

A 75-year-old female was admitted for further workup of hemoptysis. The hemoptysis started 7-10 days prior to admission and was bright red and significant in volume (often greater than half a cup). The amount increased the day prior to admission. She reported subjective fevers associated with her symptoms. She underwent a bronchoscopy at an outside hospital, which was aborted due to diffuse nonspecific bleeding in the left bronchial tree. She had a history of bronchiectasis and left lower lobectomy in 2002 for lung abscess; culture data from that infection was not available to us. Since the surgery in 2002, she experienced chronic cough and frequent respiratory infections treated with multiple rounds of antibiotics, usually Amoxicillin or Amoxicillin/Clavulanate.

On physical examination, the patient was afebrile and normotensive. Heart rate was 68 beats/minute, respiratory rate 29 breaths/minute, and oxygen saturation $98 \%$ on room air. Head and neck examination showed normal dentition with no lymphadenopathy. Chest examination showed clear breath sounds bilaterally with decreased air entry in the left lower lobe. Abdominal and cardiac exams were unremarkable.

Pertinent laboratory studies included an arterial blood gas analysis, which showed $\mathrm{pH} 7.34 / \mathrm{pCO}_{2} 75 \mathrm{~mm} \mathrm{Hg} / \mathrm{PO}_{2}$ $92 \mathrm{~mm} \mathrm{Hg} / \mathrm{bicarbonate} 40.4 \mathrm{meq} / \mathrm{L}$. The chest radiograph showed decreased lung volume in the left base and an extensive lingular and possibly left upper lobe infiltrate. Chest $\mathrm{CT}$ is shown in Figures 1(a) and 1(b). Review of her chest $\mathrm{CT}$ one year prior showed the same lingular infiltrate with a smaller size. On bronchoscopy, a yellowish, soft round body was identified in the superior lingular subsegment. This body was not immediately recognized. It was removed and sent for histologic analysis. Also, several endobronchial and transbronchial biopsies were obtained. There was subsequent significant and copious bleeding in the lingula, which was treated with intrabronchial epinephrine and resolved.

Pathology from the retrieved yellowish body revealed actinomyces species. Bronchoscopic cultures did not reveal the diagnosis. After the biopsy results were reported, the thoracic surgery service was consulted. The patient subsequently 


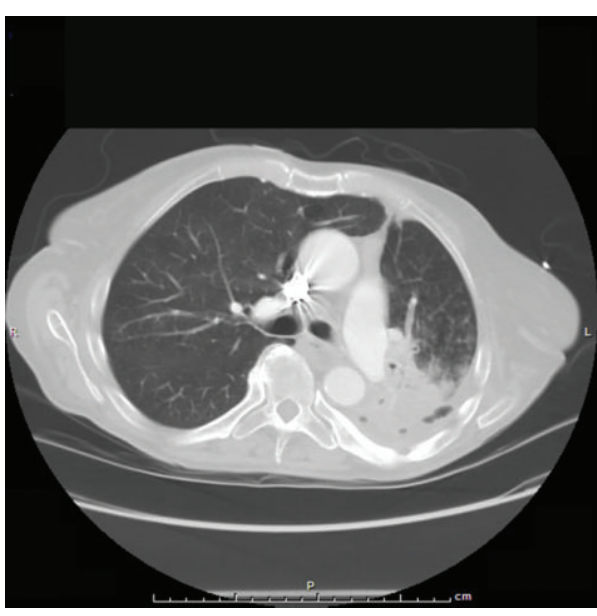

(a)

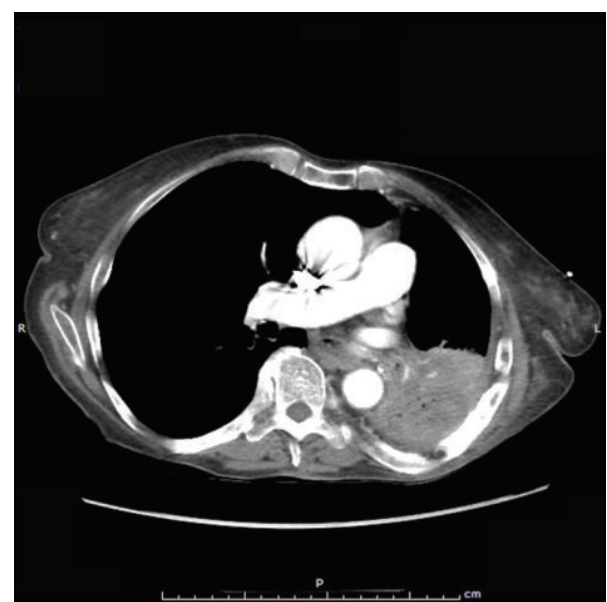

(b)

Figure 1: (a) Chest CT with "lung" windows shows an extensive dense lingular infiltrate with scattered air pockets; (b) chest CT with "soft tissue" cuts shows the same lingular infiltrate with extensive necrosis and scattered air pockets.

underwent a left modified Eloesser thoracoplasty. Postoperatively, she did very well. She had complete resolution of her hemoptysis. She also had complete resolution of her chronic cough, which had persisted for ten years. She completed a four-week course of high-dose penicillin $G$ and is being treated with a six-month course of oral amoxicillin. She is currently undergoing planning for a rotational flap to fill in the chest wall defect from the first surgery.

\section{Discussion}

Actinomycosis is a rare but indolent infection caused by anaerobic gram-positive bacteria of the genus actinomyces, with the most common pathogen being Actinomyces israelii. When first identified, the bacteria was classified as a fungus because of its yellow or whitish mycotic-like appearance. This is what was seen as a whitish body on the bronchoscopy described above. The bacteria make up the normal flora of the oropharynx and are frequently the cause of infection in patients with poor dentition. Actinomyces infection results from disruption of mucosal surfaces and can occur anywhere in the body. The classic infection is cervical disease that often presents as a large mass on the jaw or neck. The peak incidence of active infection is reported in the fourth or fifth decades of life. Male predominance exists and most infections involve immunocompetent hosts. Risk factors include alcoholism and poor oral hygiene. Actinomycosis is characterized by a pyogenic response with necrosis and can lead to severe fibrosis $[1,2]$.

Actinomycosis of the respiratory tract often results from aspiration or direct extension of disease from the head or neck. Pulmonary involvement is noted in about $15 \%$ of cases. Pulmonary actinomycosis may be complicated by unusual but significant hemoptysis due to parenchymal destruction as actinomyces can extend across fissures and even invade the chest wall. Clinically, pulmonary actinomycosis presents like a lung abscess or a nonresolving pneumonia. Patients present with indolent symptoms that evolve over weeks to months. They typically develop a nonproductive cough and low-grade fever, which progresses into a productive cough that is sometimes associated with hemoptysis. Often they will complain of characteristic features of pulmonary infection: fever, cough, sputum production, sometimes night sweats, and weight loss. Chest wall involvement and bony erosion are common. The infection can mimic metastatic disease from lung adenocarcinoma. An uncommon complication of pulmonary actinomycosis is the development of a sinus tract that appears as a bronchocutaneous fistula. Finally, at late stages, patients may manifest clubbing, anemia, and weight loss $[1,2]$.

In our case, we believe the infection evolved over a period of at least several years (although we do not have microbiologic confirmation of that), as we were able to obtain old CT scans of the chest that showed a progressively enlarging lingular necrotic area. Our patient had a chronic productive cough and low-grade fevers and was treated for pneumonia with multiple rounds of antibiotics. We believe that the antibiotics may have acted to slow the progression of this indolent infection.

Patients with indolent actinomyces infections that evolved over a period of 9 months to several years are shown in Table 1.

Diagnosis can be difficult as these bacteria are part of the normal flora and are often difficult to culture. There are currently no serologic tests that can be used for diagnosis. Bronchoscopy is often not diagnostic unless endobronchial disease is present. Bronchial washings and brushings are not helpful. Transbronchial or open lung biopsies are often in order to make the diagnosis. With the propensity of actinomycosis to mimic malignancy, diagnosis is often made after surgical resection [3].

Untreated infections will ultimately result in death, but if treatment is initiated early the rates of cure are greater than 
TABLE 1: Indolent cases of actinomycosis.

\begin{tabular}{|c|c|c|c|c|c|c|c|c|}
\hline Source & $\begin{array}{l}\text { Publication } \\
\text { year }\end{array}$ & $\begin{array}{l}\text { Age or } \\
\text { number } \\
\text { of } \\
\text { patients }\end{array}$ & Symptoms & $\begin{array}{c}\text { Hospital } \\
\text { presentation }\end{array}$ & Diagnosis & $\begin{array}{l}\text { Radiologic } \\
\text { findings }\end{array}$ & Treatment & Outcome \\
\hline Reechaipichitkul et al. [5] & 2005 & 41 years & $\begin{array}{c}\text { Fevers \& } \\
\text { hemopty- } \\
\text { sis over } 2 \\
\text { years }\end{array}$ & $\begin{array}{c}\text { Massive } \\
\text { hemoptysis }\end{array}$ & Histopathology & $\begin{array}{c}\text { Extensive } \\
\text { right upper } \\
\text { lobe infiltrate }\end{array}$ & $\begin{array}{l}\text { Emergent } \\
\text { right upper } \\
\text { lobectomy, } \\
\text { intravenous } \\
\text { augmentin } \\
\text { followed by } \\
\text { amoxicillin }\end{array}$ & $\begin{array}{l}\text { Hemoptysis } \\
\text { resolved }\end{array}$ \\
\hline Ma et al. [6] & 2009 & 66 years & $\begin{array}{c}\text { Fevers \& } \\
\text { productive } \\
\text { cough over } \\
4 \text { years }\end{array}$ & $\begin{array}{c}\text { Indolent } \\
\text { symptoms } \\
\text { of fever and } \\
\text { cough }\end{array}$ & Histopathology & $\begin{array}{c}\text { Right middle } \\
\text { lobe } \\
\text { infiltrates }\end{array}$ & $\begin{array}{c}\text { Surgical } \\
\text { resection and } \\
\text { antibiotics }\end{array}$ & $\begin{array}{l}\text { Symptoms } \\
\text { resolved }\end{array}$ \\
\hline $\begin{array}{l}\text { Dujneungkunakorn et al. } \\
\text { [7] }\end{array}$ & 1999 & $\begin{array}{c}16 \\
\text { patients }\end{array}$ & $\begin{array}{l}\text { Cough and } \\
\text { hemopty- } \\
\text { sis most } \\
\text { common; } \\
\text { mean } \\
\text { duration } \\
\text { of } \\
\text { symptoms: } \\
9 \text { months }\end{array}$ & $\begin{array}{c}\text { Indolent } \\
\text { symptoms } \\
\text { as reported }\end{array}$ & Histopathology & $\begin{array}{l}\text { Mass-like } \\
\text { shadowing } \\
\text { most } \\
\text { common } \\
(37 \%)\end{array}$ & $\begin{array}{l}\text { Surgical } \\
\text { resection in } 8 \\
\text { patients; } \\
\text { antibiotics for } \\
\text { all }\end{array}$ & $\begin{array}{l}\text { All patients } \\
\text { who had } \\
\text { surgical } \\
\text { resection were } \\
\text { cured; } 20 \% \text { of } \\
\text { antibiotic-only } \\
\text { group did not } \\
\text { respond }\end{array}$ \\
\hline
\end{tabular}

90\%. Prolonged treatment is needed, most commonly with penicillin as the drug of choice. Usually a combination of high doses of intravenous and oral antibiotics is needed. Alternative antimicrobial agents include tetracyclines, macrolides, and chloramphenicol. Surgery is indicated for bulky disease or necrotizing infections that have eroded through tissue, vasculature, or parenchyma. Relapse is common, but with treatment, long-term prognosis is good. The combination of surgery plus antibiotics has been shown in small trials to prevent relapse $[3,4]$.

It is likely the patient was spared fulminant invasive disease into her chest wall by the intermittent doses of amoxicillin she received for her recurrent pneumonias, which possibly served to suppress her actinomyces infection and delay her diagnosis.

In conclusion, pulmonary involvement in actinomycosis can mimic the presentation of lung cancer and can result in massive hemoptysis and life-threatening disease if left unchecked. Early detection is important, but diagnosis is difficulty; therefore, a high level of suspicion is needed.

\section{Conflict of Interests}

Mary Baker, MD, and Khalil Diab, MD, have no conflict of interests to report.

\section{Acknowledgment}

This case has not been presented at any previous conferences and has not been submitted to any other journals.

\section{References}

[1] G. F. Mabeza and J. Macfarlane, "Pulmonary actinomycosis," European Respiratory Journal, vol. 21, no. 3, pp. 545-551, 2003.

[2] O. Yildiz and M. Doganay, "Actinomycoses and Nocardia pulmonary infections," Current Opinion in Pulmonary Medicine, vol. 12, no. 3, pp. 228-234, 2006.

[3] M. S. Boudaya, H. Smadhi, A. Marghli et al., "Surgery in thoracic actinomycosis," Asian Cardiovascular \& Thoracic Annals, vol. 20, no. 3, pp. 314-319, 2012.

[4] J. Choi, W. J. Koh, T. S. Kim et al., "Optimal duration of IV and oral antibiotics in the treatment of thoracic actinomycosis," Chest, vol. 128, no. 4, pp. 2211-2217, 2005.

[5] W. Reechaipichitkul, T. Napaprasit, A. Puapairoj, and S. Prathanee, "Pulmonary actinomycosis presenting with prolonged fever and massive hemoptysis: a case report," Southeast Asian Journal of Tropical Medicine and Public Health, vol. 36, no. 5, pp. 1268-1271, 2005.

[6] N. Ma, Z. G. Wen, Y. H. Li, and D. J. Cui, "A case report of pulmonary actinomycosis and review of the literature," Zhonghua Jie He He Hu Xi Za Zhi, vol. 32, no. 7, pp. 485-488, 2009.

[7] T. Dujneungkunakorn, P. Riantawan, and S. Tungsagunwattana, "Pulmonary actinomycosis: a study of 16 cases from Central Chest Hospital," Journal of the Medical Association of Thailand, vol. 82, no. 6, pp. 531-535, 1999. 


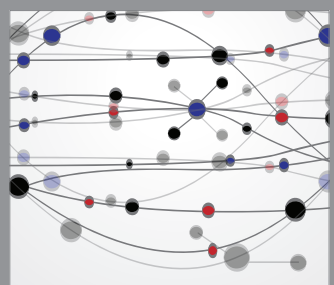

The Scientific World Journal
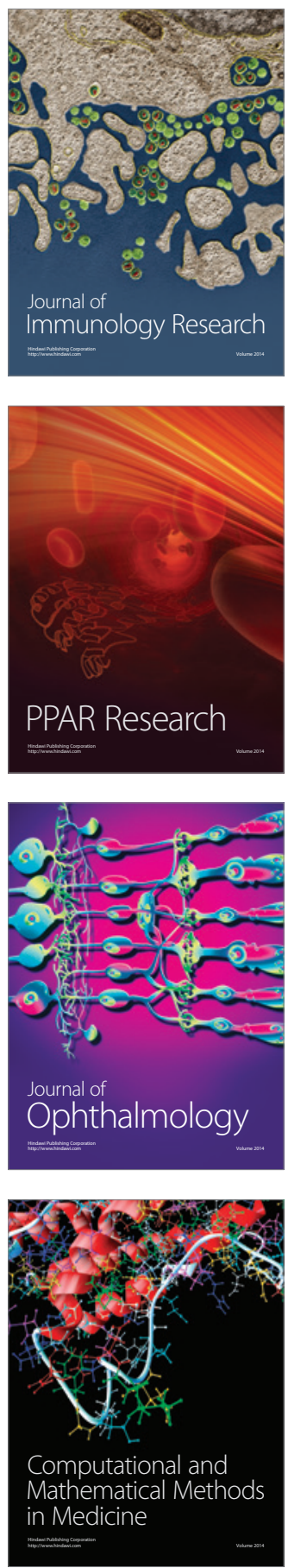

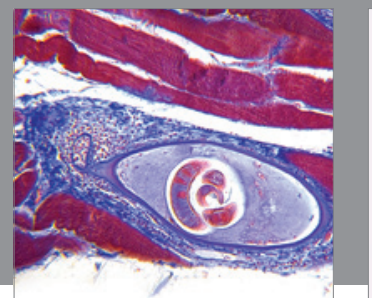

Gastroenterology

Research and Practice
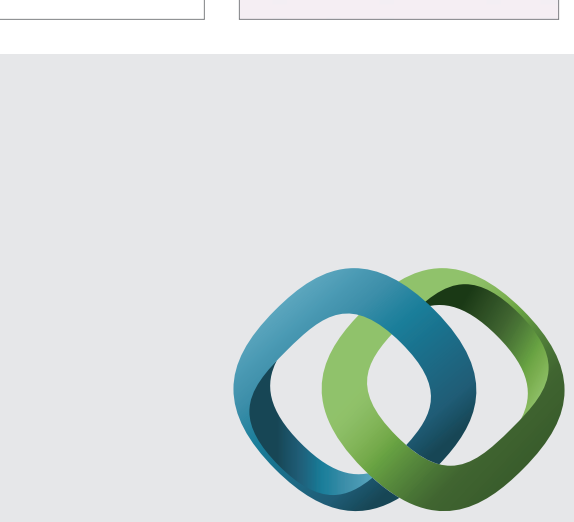

\section{Hindawi}

Submit your manuscripts at

http://www.hindawi.com
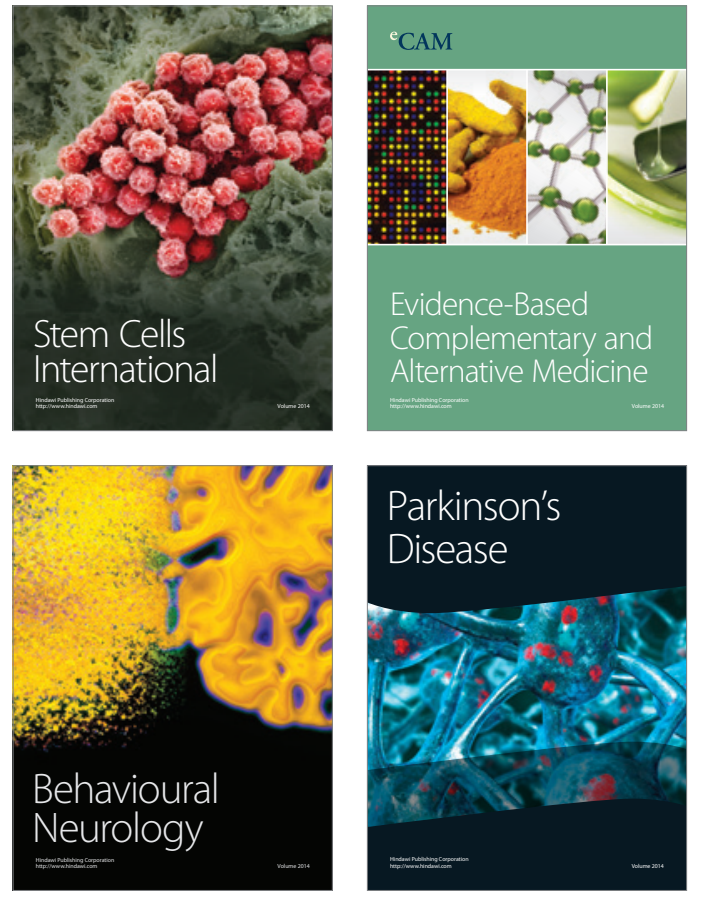
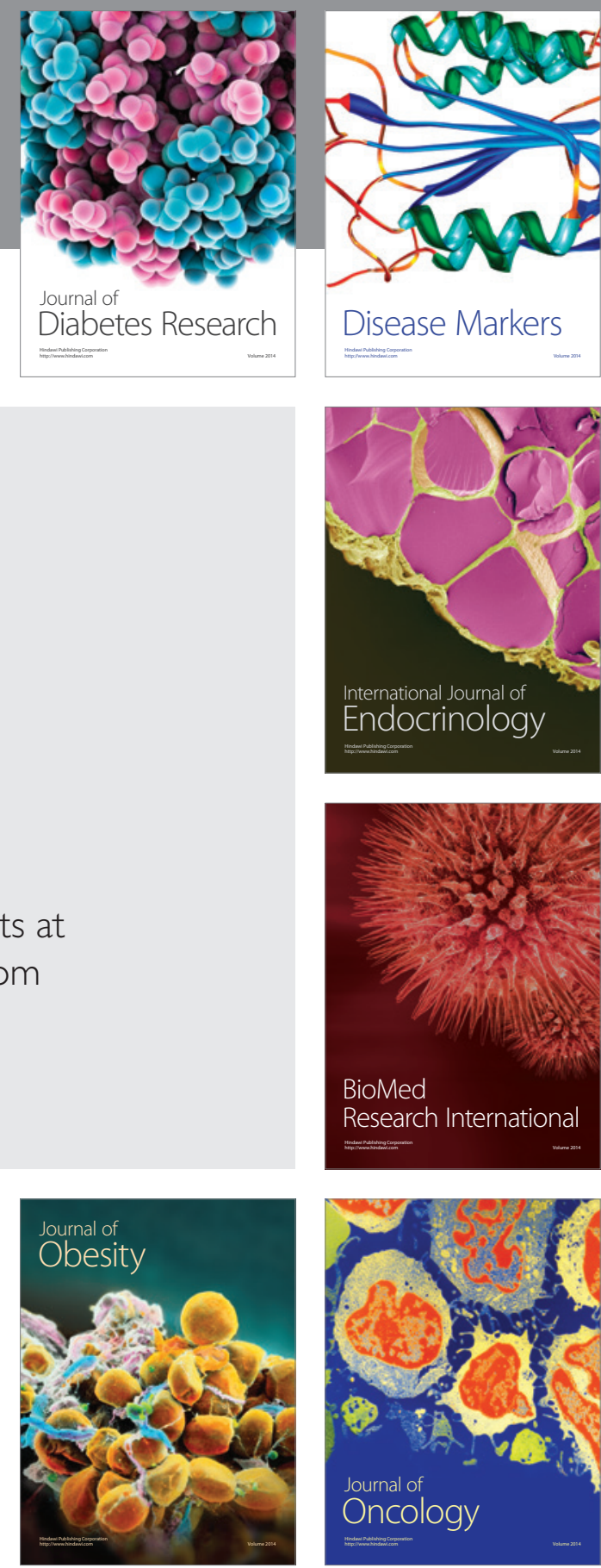

Disease Markers
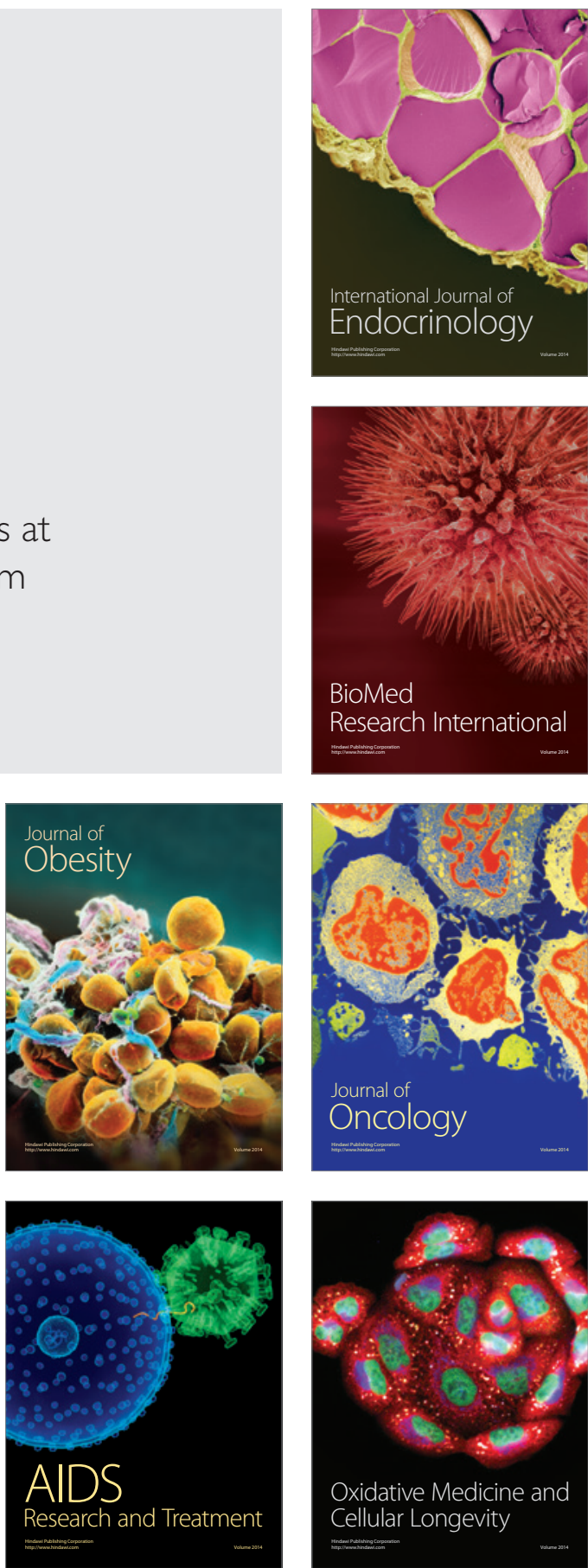